\title{
Antidiabetic and renoprotective effects of the chloroform extract of Terminalia chebula Retz. seeds in streptozotocin-induced diabetic
} rats

\author{
Nalamolu Koteswara Rao*1,2 and Srinivas Nammi ${ }^{2,3}$
}

\author{
Address: ${ }^{1}$ Pharmacology Division, GITAM Dental College, Visakhapatnam 530045, Andhra Pradesh, India, ${ }^{2}$ Pharmacology Division, Department \\ of Pharmaceutical Sciences, Andhra University, Visakhapatnam 530003, Andhra Pradesh, India and 3Section of Endocrinology and Metabolism, \\ Department of Internal Medicine, University of Manitoba, Winnipeg R3E3P4, Canada \\ Email: Nalamolu Koteswara Rao* - nalamolu_k@rediffmail.com; Srinivas Nammi - nammi@rediffmail.com \\ * Corresponding author
}

Published: 07 May 2006

BMC Complementary and Alternative Medicine 2006, 6:17 doi:10.1 186/1472-6882-6-17

This article is available from: http://www.biomedcentral.com//472-6882/6/17

(c) 2006 Rao and Nammi; licensee BioMed Central Ltd.

This is an Open Access article distributed under the terms of the Creative Commons Attribution License (http://creativecommons.org/licenses/by/2.0), which permits unrestricted use, distribution, and reproduction in any medium, provided the original work is properly cited.
Accepted: 07 May 2006
Received: 05 May 2005

\begin{abstract}
Background: Terminalia chebula (Combretaceae) has been widely used in Ayurveda for the treatment of diabetes. In the present investigation, the chloroform extract of $T$. chebula seed powder was investigated for its antidiabetic activity in streptozotocin-induced diabetic rats using short term and long term study protocols. The efficacy of the extract was also evaluated for protection of renal functions in diabetic rats.

Methods: The blood glucose lowering activity of the chloroform extract was determined in streptozotocin-induced (75 mg/kg, i.p.; dissolved in $0.1 \mathrm{M}$ acetate buffer; $\mathrm{pH} 4.5)$ diabetic rats, after oral administration at the doses of 100,200 and $300 \mathrm{mg} / \mathrm{kg}$ in short term study. Blood samples were collected from the eye retro-orbital plexus of rats before and also at 0.5, I, 2, 4, 6, 8 and $12 \mathrm{~h}$ after drug administration and the samples were analyzed for blood glucose by using glucose-oxidase/peroxidase method using a visible spectrophotometer. In long term study, the extract $(300 \mathrm{mg} / \mathrm{kg})$ was administered to streptozotocin-induced diabetic rats, daily for 8 weeks. Blood glucose was measured at weekly intervals for 4 weeks. Urine samples were collected before the induction of diabetes and at the end of 8 weeks of treatments and analyzed for urinary protein, albumin and creatinine levels. The data was compared statistically using one-way ANOVA with post-hoc Dunnet's t-test.
\end{abstract}

Results: The chloroform extract of $T$. chebula seeds produced dose-dependent reduction in blood glucose of diabetic rats and comparable with that of standard drug, glibenclamide in short term study. It also produced significant reduction in blood glucose in long term study. Significant renoprotective activity is observed in $T$. chebula treated rats. The results indicate a prolonged action in reduction of blood glucose by $T$. chebula and is probably mediated through enhanced secretion of insulin from the $\beta$-cells of Langerhans or through extra pancreatic mechanism. The probable mechanism of potent renoprotective actions of $T$. chebula has to be evaluated.

Conclusion: The present studies clearly indicated a significant antidiabetic and renoprotective effects with the chloroform extract of $T$. chebula and lend support for its traditional usage. Further investigations on identification of the active principles and their mode of action are needed to unravel the molecular mechanisms involved in the observed effects. 


\section{Background}

Diabetes mellitus is a debilitating and often life-threatening disorder with increasing incidence throughout the world [1]. Diabetic complications arise partly from glycosylation damage to structural and functional proteins and reflect chronic failure to maintain blood glucose homeostasis. Other complications such as diabetic nephropathy, diabetic retinopathy, diabetic neuropathy and diabetic cardiomyopathy prevail as a result of hyperglycemia. A scientific investigation of traditional herbal remedies for diabetes may provide valuable leads for the development of alternative drugs and strategies. Alternatives are clearly needed for better management of diabetes because of high cost and poor availability of current therapies for many rural populations, particularly in developing countries. Diabetic nephropathy is one of the microvascular complications of diabetes. The pathophysiology involves an interaction between metabolic and hemodynamic factors. Metabolic factors include advanced glycation, increased formation of polyols and activation of protein kinase-C. Hemodynamic factors include systemic hypertension, intraglomerular hypertension and the role of vasoactive hormones, such as anglotensin II. Clinical course progresses from microalbuminuria to overt proteinuria and then to renal failure [2].

The field of herbal medicines research has been gaining significant importance in the last few decades and the demand to use natural products in the treatment of diabetes is increasing worldwide. The available literature shows that there are more than 400 plant species showing antidiabetic activity $[3,4]$. Although some of these plants have great reputation in Ayurveda, the indigenous Indian system of medicine, many remain to be scientifically established [5].

The dried ripe fruit of Terminalia chebula Retz. (Combretaceae), is used extensively in Ayurveda and is widely distributed throughout India, Burma and Sri Lanka. It is commonly known as black myroblans in English and has traditionally been used in the treatment of asthma, sore throat, vomiting, hiccough, diarrhoea, bleeding piles, gout and heart and bladder diseases [6]. A herbal formulation containing $T$. chebula under the name 'TRIPHALA' is a very popular traditional medicine for the treatment of chronic disorders including diabetes $[7,8]$. It is reported to have antioxidant and free radical scavenging activities [9]. It has shown effectiveness against cancer cells [10] and helicobacter pylori [11]. It is also useful as anticaries agent [12] in dermal wound healing [13], improving gastrointestinal motility [14] and anaphylactic shock [15]. The methanolic extract of $T$. chebula has been shown to exhibit antidiabetic activity in rats [16]. Although the fruits are known for their antidiabetic properties, the whole powder of dried ripe fruits is also being widely used for the control of diabetes. So far, little is known on the medicinal values of $T$. chebula seeds. In the present study, the chloroform extract of the seeds of $T$. chebula was tested for its antidiabetic activity using short term and long term study protocols after oral administration in streptozotocin-induced diabetic rats. Moreover, the extract was also tested for its renoprotective effects upon long term study in diabetic rats.

\section{Methods \\ Plant material and extraction}

Fresh seeds of $T$. chebula were purchased from the local traders and shade dried to obtain a completely dried product. An authenticated voucher specimen (No. SP-26) of the plant has been preserved in our Department for future reference. The dried seeds were then milled to fine powder (3 kg) and extracted with chloroform in Soxhlet's apparatus for $24 \mathrm{~h}$ and the extract was evaporated to dryness under vacuum and dried in vacuum desiccator (270.8 g).

\section{Chemicals used}

Glibenclamide was a generous gift sample from Sun Pharmaceuticals Limited, Baroda, India and streptozotocin was purchased from Sigma-Aldrich, St. Louis, USA. Glucose, albumin, creatinine and protein assay kits were obtained from the Diagnostic Division of Dr. Reddy's Laboratories, Hyderabad, India. All other chemicals used were of analytical grade.

\section{Animal experiments}

Male Sprague Dawley rats procured from Mahaveer Enterprises, Hyderabad, India were used in the studies. All the animal experiments were conducted according to the protocols approved by the Institutional Animal Ethics Committee (Reg. No. 516/01/A/CPCSEA). Animals were divided into 8 groups of five each and were fed with standard diet (Ratan Brothers, Hyderabad) and water ad libitum. They were kept in clean and dry cages and maintained in well-ventilated animal house with $12 \mathrm{~h}$ light-12 h dark cycle. Rats were rendered diabetic by injecting a freshly prepared streptozotocin $(75 \mathrm{mg} / \mathrm{kg}$, i.p.; dissolved in 0.1 $\mathrm{M}$ acetate buffer; $\mathrm{pH} 4.5$ ) [17] after a base-line blood glucose estimation was done. After two weeks, animals with blood glucose levels above $450 \mathrm{mg} / \mathrm{dl}$ were selected for the study.

\section{Short term studies}

Groups I, II and III were given orally, the T. chebula extract in the form of suspension in $1 \%$ sodium CMC at doses of 100, 200 and $300 \mathrm{mg} / \mathrm{kg}$ respectively. Group IV was served as control and received equivalent volumes of vehicle. Group V received glibenclamide at a dose of $0.04 \mathrm{mg} / \mathrm{kg}$ and served as standard. Animals were fasted for $16 \mathrm{~h}$ prior to drug administration allowing access only to water. Blood samples were collected from retro-orbital plexus of 
each rat before and also at $0.5,1,2,4,6,8$ and $12 \mathrm{~h}$ after treatments. The samples were analyzed for blood glucose content by using glucose-oxidase/peroxidase method $[18,19]$ with optical density measured at $505 \mathrm{~nm}$ using a visible spectrophotometer.

\section{Long term studies}

For long term evaluation, groups of rats were given daily treatments for 8 weeks. Animals in group VI were given orally, the $T$. chebula extract (suspended in 1\% sodium $\mathrm{CMC}$ ) at a dose of $300 \mathrm{mg} / \mathrm{kg}$. Group VII served as control while group VIII received glibenclamide at a dose of 0.04 $\mathrm{mg} / \mathrm{kg}$. Blood samples were collected from the overnight fasted animals and fasting blood glucose levels were measured before and also at weekly intervals for 4 weeks. For urinary collection, rats were housed in metabolic cages at the start (pre-diabetic condition) and at the end ( $8^{\text {th }}$ week) of the experiment. The $24 \mathrm{~h}$ urinary samples were collected from all the animals after have been acclimatized in metabolic cages for 3 days. The measurements of urinary protein [20], albumin [21] and creatinine [22] were done using commercial diagnostic kits following manufacturer's instructions.

\section{Statistical analysis}

Data are expressed as mean \pm standard error of mean. Statistical analysis was done using one-way analysis of variance (ANOVA) and post-hoc comparisons were carried out using Dunnet's $t$-test. P values $<0.05$ were considered as significant.

\section{Results}

\section{Short term studies}

The chloroform extract of $T$. chebula seeds produced significant antidiabetic effect with various doses in streptozotocin-induced diabetic rats in acute study. It produced a dose-dependent reduction in blood glucose with doses of 100, 200 and $300 \mathrm{mg} / \mathrm{kg}$ compared to control group (Table 1). Glibenclamide $(0.04 \mathrm{mg} / \mathrm{kg})$ also produced a significant reduction in blood glucose compared to control group. T. chebula produced a maximum reduction of blood glucose of $20.85 \%$ ( $p<0.01), 28.45 \%(p<0.001)$ and $42.20 \%(\mathrm{p}<0.001)$ at $4 \mathrm{~h}$ with doses of 100, 200 and $300 \mathrm{mg} / \mathrm{kg}$ respectively, where as glibenclamide $(0.04 \mathrm{mg} /$ $\mathrm{kg}$ ) produced a maximum reduction of $50.44 \%$ ( $4 \mathrm{~h}, \mathrm{p}<$ $0.001)$ compared to control group.

\section{Long term studies}

Long term administration of $T$. chebula $(300 \mathrm{mg} / \mathrm{kg})$ to streptozotocin-induced diabetic rats for four weeks produced significant reduction in blood glucose. The reduction was significant after treatment for one week in both the extract and glibenclamide treated groups and continued to increase up to four weeks (Table 2). At the end of $4^{\text {th }}$ week, T. chebula extract produced significant blood glu- cose reduction of $53.09 \%(\mathrm{p}<0.01)$. On the other hand, glibenclamide produced significant blood glucose reduction of $60.10 \%(p<0.01)$.

The urinary excretion profile of protein, albumin and creatinine is shown in Figure 1. Streptozotocin-induced diabetic rats displayed a significant $(\mathrm{p}<0.001)$ increase in urinary protein, albumin and creatinine after 8 weeks as compared to their pre-diabetic state levels. However, rats
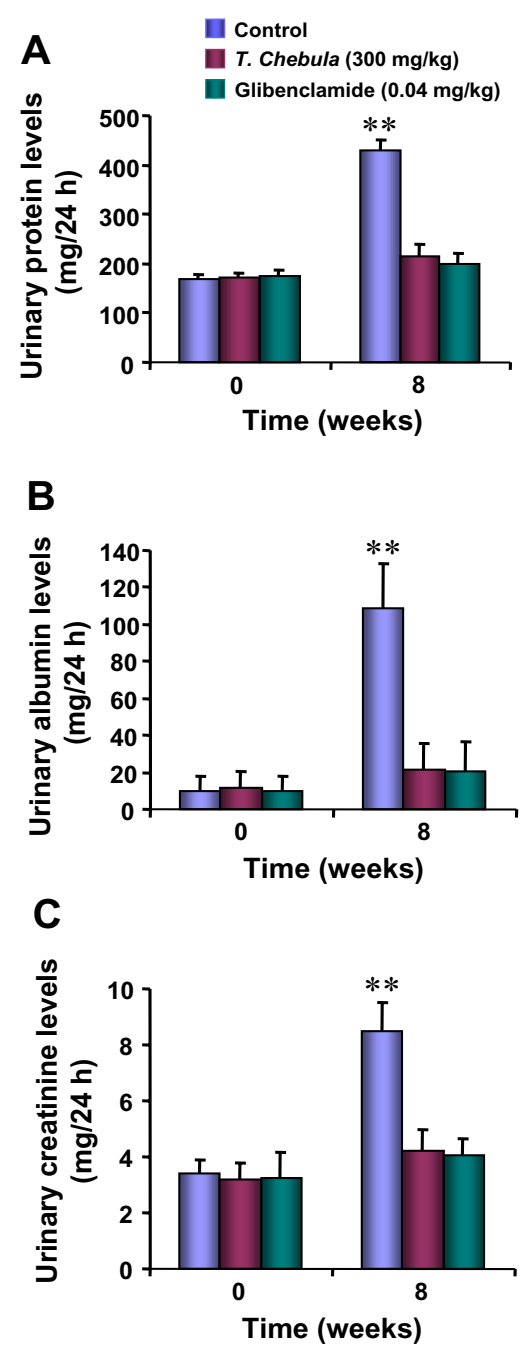

Figure I

Effect of T.chebula on urinary excretion of protein (A), albumin (B) and creatinine (C) in streptozotocin-induced diabetic rats. Each bar indicates the mean \pm SEM of 5 animals in each group. Urine samples were collected before the induction of diabetes ( 0 week) and after 8 weeks of daily treatments either with vehicle (control), $T$. chebula $(300 \mathrm{mg} / \mathrm{kg})$ or glibenclamide $(0.04 \mathrm{mg} / \mathrm{kg})$ in streptozotocin-induced diabetic rats. Significant difference from the corresponding pre-diabetic value: ${ }^{* *} p<0.001$. 
Table I: Percent blood glucose reduction produced by T.chebula after oral administration in streptozotocin-induced diabetic rats.

\begin{tabular}{|c|c|c|c|c|c|c|c|c|}
\hline \multirow{2}{*}{$\begin{array}{l}\text { Group }(n= \\
5)\end{array}$} & \multirow{2}{*}{$\begin{array}{l}\text { Dose (mg/ } \\
\text { kg) }\end{array}$} & \multicolumn{7}{|c|}{ Percent blood glucose reduction } \\
\hline & & 0.5 & $\mathbf{I}$ & 2 & 4 & 6 & 8 & 12 (hrs) \\
\hline Control & --- & $-5.65 \pm 1.80$ & $-8.10 \pm 3.29$ & $-1.35 \pm 6.62$ & $-12.09 \pm 4.48$ & $-7.25 \pm 4.90$ & $-4.19 \pm 2.08$ & $-7.03 \pm 8.15$ \\
\hline T.chebula & 100 & $-2.18 \pm 3.95$ & $8.45 \pm 9.27$ & $17.82 \pm 5.38^{*}$ & $20.85 \pm 5.29 *$ & $19.94 \pm 6.18^{*}$ & $10.98 \pm 8.54$ & $8.36 \pm 3.18$ \\
\hline T.chebula & 200 & $1.28 \pm 4.72$ & $20.28 \pm 6.29 *$ & $\begin{array}{c}31.98 \pm \\
8.24^{* *}\end{array}$ & $\begin{array}{c}28.45 \pm \\
6.20 * *\end{array}$ & $\begin{array}{c}26.55 \pm \\
2.70^{* * *}\end{array}$ & $|8.25 \pm 5.2|^{*}$ & $12.86 \pm 8.20^{*}$ \\
\hline T.chebula & 300 & $-1.18 \pm 4.25$ & $\begin{array}{l}25.88 \pm \\
10.05^{* *}\end{array}$ & $\begin{array}{c}38.92 \pm \\
7.18^{* * *}\end{array}$ & $\begin{array}{l}42.20 \pm \\
4.65^{* * *}\end{array}$ & $\begin{array}{c}33.09 \pm \\
8.05^{* *}\end{array}$ & $\begin{array}{c}27.85 \pm \\
4.78 \text { ** }\end{array}$ & $\begin{array}{c}22.90 \pm \\
7.55^{* *}\end{array}$ \\
\hline Glibenclamide & 0.04 & $24.92 \pm 8.20 *$ & $\begin{array}{c}32.37 \pm \\
4.60 * *\end{array}$ & $\begin{array}{l}38.72 \pm \\
10.22 * *\end{array}$ & $\begin{array}{c}50.44 \pm \\
8.40 * *\end{array}$ & $\begin{array}{c}46.56 \pm \\
4.60 * *\end{array}$ & $23.11 \pm 6.75^{*}$ & $10.26 \pm 11.03$ \\
\hline
\end{tabular}

Values are represented as mean \pm SEM.; $n=$ number of animals per group

Significant difference from control group at identical times, $* \mathrm{P}<0.01$; $* * \mathrm{P}<0.00$ I

treated with $T$. chebula $(300 \mathrm{mg} / \mathrm{kg})$ or glibenclamide $(0.04 \mathrm{mg} / \mathrm{kg})$ for 8 weeks did not produce any change in urinary protein, albumin or creatinine compared to their corresponding pre-diabetic values.

\section{Discussion}

Diabetes mellitus is possibly the World's largest growing metabolic disorder, and as the knowledge on the heterogeneity of this disorder is advanced, the need for more appropriate therapy increases [23]. The enormous costs of modern medicines indicate that alternative strategies are required for better management of diabetes. Traditional plant medicines are used throughout the world for a range of diabetic complications. The study of such medicines might offer a natural key to unlock a diabetologist's pharmacy for the future.

For the study of antidiabetic agents, streptozotocininduced hyperglycemia in rodents is considered to be a good preliminary screening model and is widely used [24]. Streptozotocin, N- [methylnitrocarbamoyl]-D-glucosamine is a potent methylating agent for DNA and acts as nitric oxide donor in pancreatic $\beta$-cells and thus $\beta$-cells are more sensitive to damage by nitric oxide and free radical scavenging enzymes [25]. T. chebula is widely used as a traditional medicine by diabetic patients in India.
Although the fruits are known for their antidiabetic properties, the whole powder of dried ripe fruits is also being widely used for the control of diabetes. So far, little is known on the medicinal values of $T$. chebula seeds. In the present study the chloroform extract of the seeds of $T$. chebula was evaluated and the data also confirmed the traditional indications. Our data on the seed extract of $T$. chebula indicated a potent action in short term study and a prolonged duration of antidiabetic action in long term study and this could be due to multiple sites of action possessed by the active principles of $T$. chebula.

The study also revealed that $T$. chebula is more effectively inhibited the incidence of diabetic nephropathy. Diabetic nephropathy is mainly associated with excess urinary albumin excretion, abnormal renal function as represented by an abnormality in serum creatinine. The common progression from microalbuminuria to overt nephropathy has led many to consider microalbuminuria to define early or incipient nephropathy. Renal disease is suspected to be secondary to diabetes in the clinical setting of long-standing diabetes. Clinically, diabetic nephropathy is characterized by a progressive increase in proteinuria and decline in GFR, hypertension, and a high risk of cardiovascular morbidity and mortality. The pathophysiology involves glucose that binds irreversibly to pro-

Table 2: Percent blood glucose reduction produced by $T$. chebula after chronic administration in streptozotocin-induced diabetic rats

\begin{tabular}{|c|c|c|c|c|c|}
\hline \multirow[t]{2}{*}{ Group $(n=5)$} & \multirow[t]{2}{*}{ Dose (mg/kg) } & \multicolumn{4}{|c|}{ Percent blood glucose reduction } \\
\hline & & $\mathbf{I}$ & 2 & 3 & 4 (Weeks) \\
\hline Control & ---- & $-19.72 \pm 8.05$ & $-14.35 \pm 4.92$ & $-7.06 \pm 4.28$ & $-12.48 \pm 7.55$ \\
\hline T. chebula & 300 & $38.75 \pm 8.09 *$ & $45.20 \pm 11.64^{*}$ & $48.10 \pm 5.25^{*}$ & $53.09 \pm 3.14^{*}$ \\
\hline Glibenclamide & 0.04 & $48.09 \pm 10.90 *$ & $55.75 \pm 8.03^{*}$ & $58.88 \pm 5.08 *$ & $60.10 \pm 2.70 *$ \\
\hline
\end{tabular}

Values are represented as mean \pm S.E.M.; $n=$ number of animals per group

Significant difference from control group at identical times, $* \mathrm{P}<0.0$ I 
teins in the kidney and circulation to form advanced glycosylation end products (AGEs). AGEs can form complex crosslinks over years of hyperglycemia and can contribute to renal damage by stimulation of growth and fibrotic factors via receptors for AGEs. Increased glomerular capillary pressure occurs early in diabetes and is associated with hyperfiltration at the glomerulus. The glomerular mesangium expands, initially by cell proliferation and then by cell hypertrophy. Increased mesangial stretch and pressure can stimulate this expansion, as can high glucose levels. Mediators of proliferation and expansion include platelet-derived growth factor and transforming growth factor- $\beta$ (TGF- $\beta$ ). TGF- $\beta$ are particularly important in the mediation of expansion and later fibrosis via the stimulation of collagen and fibronectin. Angiotensin-II (AT-II) also contributes to the progression of diabetic nephropathy. AT-II preferentially constricts the efferent arteriole in the glomerulus, leading to higher glomerular capillary pressure. In addition to its hemodynamic effects, AT-II also stimulates renal growth and fibrosis through AT-II type 1 receptors, which secondarily upregulate TGF- $\beta$ and other growth factors. The extract due to its significant hypoglycemic activity may have inhibited the formation of advanced glycosylation end products. However the extract may also have effect on the above stated other mechanisms.

Further work on fractionation, purification, identification of active principle(s) and detailed mechanistic evaluation responsible for these activities are obviously required on the seeds of $T$. chebula. The possible mechanisms behind the hypoglycemic activity and the inhibition of incidence of diabetic nephropathy are yet to be studied.

\section{Conclusion}

In conclusion, the present studies indicated a significant antidiabetic and renoprotective effects with the chloroform extract of Terminalia chebula and support its traditional usage in the control of diabetes and its complications. Further investigations to identify the active principle(s) are obviously needed together with a detailed evaluation on the mechanisms involved in the observed activities.

\section{Competing interests}

The author(s) declare that they have no competing interests.

\section{Authors' contributions}

NKR conceived the study, made significant contributions in data analysis, data interpretation, writing of the manuscript and in coordination of the experiments. SN made substantial contributions in conceptualization of statistical analyses, drafting the final manuscript and designing the illustrations. All authors read and approved the final manuscript.

\section{Acknowledgements}

The authors are grateful to Sun Pharmaceuticals Limited (Baroda, India) for supplying glibenclamide as a generous gift sample. The authors are also thankful to the Department of Pharmaceutical Sciences Andhra University, Visakhapatnam, India for providing all the facilities to carryout the studies.

\section{References}

I. World Health Organization: Diabetes mellitus: Report of a WHO study group. WHO Technical Report Series 1985:727.

2. Annapurna A, Kumar VK, Rao NK, Harish G, Kumar KV: Diabetic nephropathy. Ind J Pharm Sci 200I, 63:273-278.

3. Rai MK: A review on some antidiabetic plants of India. Ancient Sci Life 1995, 14:42-54.

4. Mukherjee SK: Indigenous drugs in diabetes mellitus. J Diabet Assoc Ind 198I, $21: 97-106$.

5. Marles RJ, Farnsworth NR: Antidiabetic plants and their active constituents. Phytomedicine 1995, 2:137-189.

6. Kirtikar KR, Basu BD: Terminalia chebula. In Indian Medicinal Plants Volume I. 2nd edition. Edited by: Kirtikar KR, Basu BD. Allahabad: Lalit Mohan Basu Publications; 1935:1020-1023.

7. Triphala [http://www.drroopas.com/triphala.htm]

8. Terminalia Chebula/Myrobalan/Hardad/Chebulic Myrobalan/Haritaki/Harada [http://www.herbalremedies.com/terminaliachebula-information.html]

9. Cheng HY, Lin TC, Yu KH, Yang CM, Lin CC: Antioxidant and free radical scavenging activities of Terminalia chebula. Biol Pharm Bull 2003, 26:133|-1335.

10. Saleem A, Husheem M, Harkonen P, Pihlaja K: Inhbition of cancer cell growth by crude extract and the phenolics of Terminalia chebula Retz. fruit. J Ethnopharmacol 2002, 81:327-336.

II. Malekzadeh F, Ehsanifar H, Shahamat M, Levin M, Colwell RR: Antibacterial activity of black myroblan (Terminalia chebula Retz.) against Helicobacter pylori. Int J Antimicrob Agents 200I, 18:85-88.

12. Suguna L, Singh S, Sivakumar P, Sampath P, Chandrakasan G: Influence of Terminalia chebula on dermal wound healing in rats. Phyther Res 2002, 16:227-231.

13. Jagtap AG, Karkera SG: Potential of the aqueous extract of Terminalia chebula as an anticaries agent. J Ethnopharmacol 1999, 68:299-306.

14. Tamhane MD, Thorat SP, Rege NN, Dahanukar SA: Effect of oral administration of Terminalia chebula on gastric emptying: an experimental study. J Postgrad Med 1997, 43:12-13.

15. Shin TY, Jeong HJ, Kim DK, Kim SH, Lee JK, Kim DK, Chae BS, Kim JH, Kang HW, Lee CM, Lee KC, Park ST, Lee EJ, Lim JP, Kim HM, Lee YM: Inhibitory action of water soluble fraction of Terminalia chebula on systemic and local anaphylaxis. J Ethnopharmacol 200I, 74:133-140.

16. Sabu MC, Kuttan R: Antidiabetic activity of medicinal plants and its relationship with their antioxidant properties. J Ethnopharmacol 2002, 81 : I55-160.

17. Singh SN, Praveen V, Shoba S, Shyam R, Kumaria MML, Ranganathan $S$, Sridharan K: Effect of an antidiabetic extract of Catharanthus roseus on enzymatic activities in Streptozotocin induced diabetic rats. J Ethnopharmacol 2001, 76:269-277.

18. Trinder P: Determination of blood glucose using an oxidaseperoxidase system with a non-carcinogenic chromogen. J Clin Pathol 1969, 22:|58-16|.

19. Murthy BK, Nammi S, Kota MK, Rao RVK, Rao NK, Annapurna A: Evaluation of hypoglycemic and antihyperglycemic effects of Datura metel (Linn.) seeds in normal and alloxan-induced diabetic rats. J Ethnopharmacol 2004, $91: 95-98$.

20. Lowry OH, Rosebrough NJ, Farr A, Randall R: Protein determination with the Folin's reagent. J Biol Chem I95I, I95:I33-I40.

21. Kumar KV, Naidu MUR, Anwar AS, Ratnakar KS: Probucol protects against gentamycin-induced nephrotoxicity in rats. Ind J Pharmacol 2002, 32:108-1 I3.

22. Bartels $H$, Bohmer M, Heieri C: Serum creatinine determination without protein precipitation. Clin Chem Acta 1972, 37:193-196. 
23. Baily CJ, Flatt PR: Antidiabetic drugs, new developments. Ind Biotech 1986, 6: 139-142.

24. Ivorra MD, Paya M, Villar A: A review of natural products and plants as potential antidiabetic drugs. J Ethnopharmacol 1989, 27:243-275.

25. Lukic ML, Stosic-Grujicic S, Shahin A: Effector mechanism in low dose streptozotocin induced diabetes. Develop Immunol 1998, 6:119-128.

\section{Pre-publication history}

The pre-publication history for this paper can be accessed here:

http://www.biomedcentral.com/1472-6882/6/17/prepub

Publish with Biomed Central and every scientist can read your work free of charge

"BioMed Central will be the most significant development for disseminating the results of biomedical research in our lifetime. " Sir Paul Nurse, Cancer Research UK

Your research papers will be:

- available free of charge to the entire biomedical community

- peer reviewed and published immediately upon acceptance

- cited in PubMed and archived on PubMed Central

- yours - you keep the copyright

Submit your manuscript here:

http://www.biomedcentral.com/info/publishing_adv.asp 